\title{
Modern sedimentation processes in Laguna de Medina, southern Spain, derived from lake surface sediment and catchment soil samples
}

\author{
Jasmijn van 't HOFF, ${ }^{*}$ Tabea SCHRÖDER, ${ }^{2}$ Peter HELD, ${ }^{1}$ Stephan OPITZ, ${ }^{3}$ Bernd WAGNER,,${ }^{1}$ Klaus REICHERTER, \\ Martin MELLES ${ }^{1}$ \\ ${ }^{1}$ Institute of Geology and Mineralogy, University of Cologne, Zuelpicher Str. 49a, 50674 Cologne; ${ }^{2}$ Institute of Neotectonics and \\ Natural Hazards, RWTH Aachen University, Lochnerstr. 4-20, 52056 Aachen; ${ }^{3}$ Institute of Geography, University of Cologne, \\ Albertus-Magnus-Platz, 50923 Cologne, Germany \\ *Corresponding author: jvanthof@uni-koeln.de
}

\begin{abstract}
Modern processes influencing sediment composition in the endorheic lake Laguna de Medina, southern Spain, are disentangled by analysis of 46 lake surface sediment and 32 catchment soil samples. Based on statistical analysis of the mineralogical, geochemical, elemental, and granulometric compositions of all samples, the lake surface sediments can be divided into six provinces of individual composition and depositional processes. High quartz contents and coarse grain sizes, reflecting input from ancient terraces of the Guadalete River that are exposed in the adjacent hinterland, characterize the lake sedimentation close to the northern shore. At the south-eastern shore, sedimentation is characterized by terrestrial input of the Triassic Keuper facies via the most important inlet, the Arroyo Fuente Bermeja, as reflected by high relative intensities of $\mathrm{Ti}, \mathrm{K}, \mathrm{Al}, \mathrm{Fe}, \mathrm{Mg}, \mathrm{Rb}$. Sediments close to the southern shore are characterized by high calcite contents, reflecting predominant sediment supply from the adjacent Cretaceous 'capas rojas', a series of Subbetic deep-water marlstones and limestones. Close to the western shore, relatively high gypsum contents presumably are due to precipitation from upwelling ground water. Anthropogenic influence is only indicated in the north-western and central eastern parts of the lake, where the surface sediments are significantly enriched in TOC and TN, reflecting enhanced primary production due to terrestrial organic matter supply from anthropogenic areas in the respective catchment. The central part of the lake is characterized by distal hemipelagic sedimentation, with high concentrations of clay and silt and a chemical and mineralogical composition that reflects a mixture of the sediment sources characterizing individual parts of the lake shores. The results of this study shed new light on the depositional processes and their potential spatial heterogeneity in small endorheic lakes. Furthermore, they will provide important information concerning the interpretation of the climate-controlled sedimentary processes through time, which are reflected in a 25.7 $m$ long sediment record (Co1313) that was recovered in the lake centre in 2014 and 2015.
\end{abstract}

Key words: Limnology; modern sedimentation patterns; Laguna de Medina; southern Spain.

Received: May 2016. Accepted: September 2016.

\section{INTRODUCTION}

Spain, especially the arid southern Spain, is very vulnerable to the ongoing climate change. For instance, the average air temperature rose $2-3^{\circ} \mathrm{C}$ since the 1970 's (de Castro et al., 2004). The annual rainfall is reduced and droughts are increased since 1960 (Met Office, 2011). According to climate simulations, temperature over the next 30 years may rise another $1.1-1.2^{\circ} \mathrm{C}$ during winter and $1.8-2.0^{\circ} \mathrm{C}$ during summer, and precipitation may decrease by 7 to $9 \mathrm{~mm}$ month $^{-1}$, leading to water stress for $25-60 \%$ of Spain's population (von Storch et al., 1993; Met Office, 2011; Stocker et al., 2013). Taking the more arid conditions of southern Spain, it can be expected that this region suffers more from water stress than the more humid northern Spain.

Comparatively little is known about the natural climatic variability in southern Spain on millennial timescales, beyond the range of meteorological measure- ments, and its impact on the regional environment. Such information is important to decipher the kind and rates of the spatial extend, magnitude, and temporal relationships of climatic forcing and environmental change. Most of the terrestrial archives only cover parts of the Holocene, have poor time resolution or age control, or are highly discontinuous (Reed et al., 2001; Fletcher et al., 2007; MartinPuertas et al., 2008; Wolf and Faust, 2015). Only a few sediment cores, from the Padul peat bog and the Fuentillejo Maar, penetrate into sediments representing the Last Glacial Maximum (Pons and Reille, 1988; Vegas et al., 2010). Consequently, our current understanding of the Late Pleistocene history of southern Spain, including its vegetation history, is predominantly based on data from marine sediment records, specifically from the Atlantic margin off Portugal (Voelker and de Abreu, 2011), the Gulf of Cádiz (Toucanne et al., 2007), and the Alboran Sea (Martrat et al., 2014; Martinez-Ruiz et al., 2015). These records, however, integrate over large areas and 
thus lack sensitivity to detect the influence of climatic changes on regional scales.

One promising continental archive in southern Spain is the sediment record in the Laguna de Medina (Fig. 1a). In this small endorheic lake, a 10-m sediment core was retrieved by Reed et al. (2001). According to chronostratigraphic, lithological information and palaeoenvironmental recontructions, these sediments were continuously deposited during the past 9000 years and reflect the regional environmental change with a high sensitivity. In order to extend the record in time, and to provide more material for further analyses also in the upper part, the record in the central part of the Laguna de Medina (site Co1313) was extended to $25.7 \mathrm{~m}$ during two coring campaigns in September 2014 and March 2015.

For a better understanding of the core composition and its significance for past environmental and climatic settings, 46 lake surface sediment and 32 catchment soil samples were taken, and analysed for their mineralogical, geochemical, elemental, and granulometric composition. Here, we present the data obtained from the surface samples, and discuss them in the light of the modern sedimentation processes, mainly controlled by the surrounding geology, post-depositional processes, and anthropogenic influences.

\section{Study area}

Laguna de Medina $\left(36^{\circ} 37^{\prime} 04^{\prime} \mathrm{N}, 06^{\circ} 03^{\prime} 13^{\prime \prime} \mathrm{W}\right)$ is an endorheic semi-permanent karst lake (Valero-Garcés et al., 2014) in southern Spain (Fig. 1a), located roughly $12 \mathrm{~km}$ southeast of Jerez, $25 \mathrm{~km}$ northeast of Cádiz and about $3 \mathrm{~km}$ south of the river Rio Guadalete. This second largest inland salt lake of Andalucía is a nature reserve since 1987 (de Vicente et al., 2012). It is located $16 \mathrm{~m}$ above sea level (asl), the surface area amounts to $1.2 \mathrm{~km}^{2}$, and the catchment area to $16 \mathrm{~km}^{2}$ (Reed et al., 2001). At the south-eastern shore, the most important inlet, the Arroyo Fuente Bermeja, enters the lake. This is a temporary inflow, which is dry during summer months (Reed et al., 2001). In September 2014 and March 2015, the maximum water depths were $1.7 \mathrm{~m}$ and $3.2 \mathrm{~m}$, and the salinities 6.0 PSU and 2.2 PSU, respectively.

The catchment of the Laguna de Medina (Fig. 1b) is karstic and evaporitic (Durán Valsero et al., 2009), dominated by terrestrial Triassic claystones (Keuper facies), gypsum-rich evaporites, and marlstones (Paez, 1991). The inlet Arroyo de Fuente Bermejo predominantly drains the Triassic Keuper facies (claystones, sandstones, dolomites, and gypsum). The eastern area of the lake also is dominated by Triassic units (IGME, 1984). In the north, remnants of alluvial terraces of Pleistocene sandstones and conglomerates of about 45 to $50 \mathrm{~m}$ asl demarcate the border of the lake. The southern area of the lake is characterized by the 'capas rojas', a series of Subbetic deep-water marlstones and limestones (Vera and Molina, 1999). In the western catchment, Tertiary clays, marls, calcarenites, and biomicrites occur (IGME, 1984).

The lake was formed as a result of 20 to $25 \mathrm{~m}$ diapiric uplift (Rodriguez Vidal et al., 1993), initiated by the high vulnerability of Triassic and Tertiary marls to halokinetic deformation (Wolf et al., 2014). The appearance of diapirs started in the Upper Miocene and has been related to extensional or compressional tectonics in the Gulf of Cádiz (Medialdea et al., 2009). In the Middle Pleistocene, the Rio Guadalete left the elevated areas and found its way in the valleys. The ground water dropped below the karst base level, resulting in sinkholes and the prolapse of old sinkholes. Laguna de Medina is an example of renewed karst sinking in Triassic gypsums, formed in the Upper Pleistocene (Rodriguez Vidal et al., 1993; Valero-Garcés et al., 2014). The modern configuration of the lake basin was probably established during the Late Pleistocene (Rodriguez Vidal et al., 1993).

Laguna de Medina today experiences a Mediterranean climate (Peel et al., 2007). During summer, average temperatures of $26^{\circ} \mathrm{C}$ occur and the precipitation is very low, with a five-months period of water deficit. Meso-scale levanters, easterlies with velocities of $10-20 \mathrm{~m} / \mathrm{s}$, are frequent (Meteorological Office, 1962). The winters are characterized by an average temperature of $6^{\circ} \mathrm{C}$ and a relatively high precipitation of up to $90 \mathrm{~mm}$ per month (Paez, 1991). Both the levanters and the westerlies are weaker and less frequent than during summer (Dorman et al., 1995). The intensity and distribution of precipitation in the area is particularly influenced by the Azores High (Rodrigo et al., 2001) and by fluctuations of the North Atlantic Oscillation (Wolf et al., 2014). The mean annual precipitation is 525 $\mathrm{mm}$, with a range of 250-975 mm (Paez, 1991).

The Laguna de Media is a shallow saline lake functioning as a hydrologically closed system (FernándezPalacios, 1990). Nevertheless, there is a significant influence of ground-water inflow, which leads to the retention of water during summer times (Reed et al., 2001). The ground-water inflow is characterized by high salinities, due to dissolution of Triassic evaporites. This leads to a brine in the lake that consists of Ca-Na-Mg-Cl- $-\mathrm{SO}_{4}$, thus resulting in gypsum precipitation (Eugster and Hardie, 1978). However, the groundwater infiltration is very low, due to little permeable underground (Fernández-Palacios, 1990), which makes the lake very vulnerable to variations in precipitation. Today, the lake level is highly affected by the seasonal precipitation changes, resulting in summer desiccation in very arid years. Longterm studies from Furest and Toja (1984), Marazanof (1967), and Reed et al. (2001) show a connection between lake level and salinity changes, especially after irrigation since 1948 (Tello Ripa and López Bermúdez, 1988). On the other hand, the relation between lake level and salinity 
is complex, because of re-dissolution of precipitated salts and gypsum, leading to an increase in salinity with an increasing lake level (Reed et al., 2001).

\section{METHODS}

In March 2015, 46 surface sediment samples were taken from the uppermost $2 \mathrm{~cm}$ of the lake bottom (Fig. 1c).
The samples were retrieved from a rubber boat using a gravity corer with a plastic liner of $63 \mathrm{~mm}$ diameter (UWITEC Corp., Mondsee, Austria). The sampling location was noted in the moment the gravity corer hit the lake bottom. Sampling partly failed close to the northern shore, where coarse sand and gravel dominate. The lake sediment sample set is complemented by 25 soil samples from the uppermost $5-10 \mathrm{~cm}$ in the catchment and 7 sediment samples from the Arroyo Fuente Bermeja, the only significant
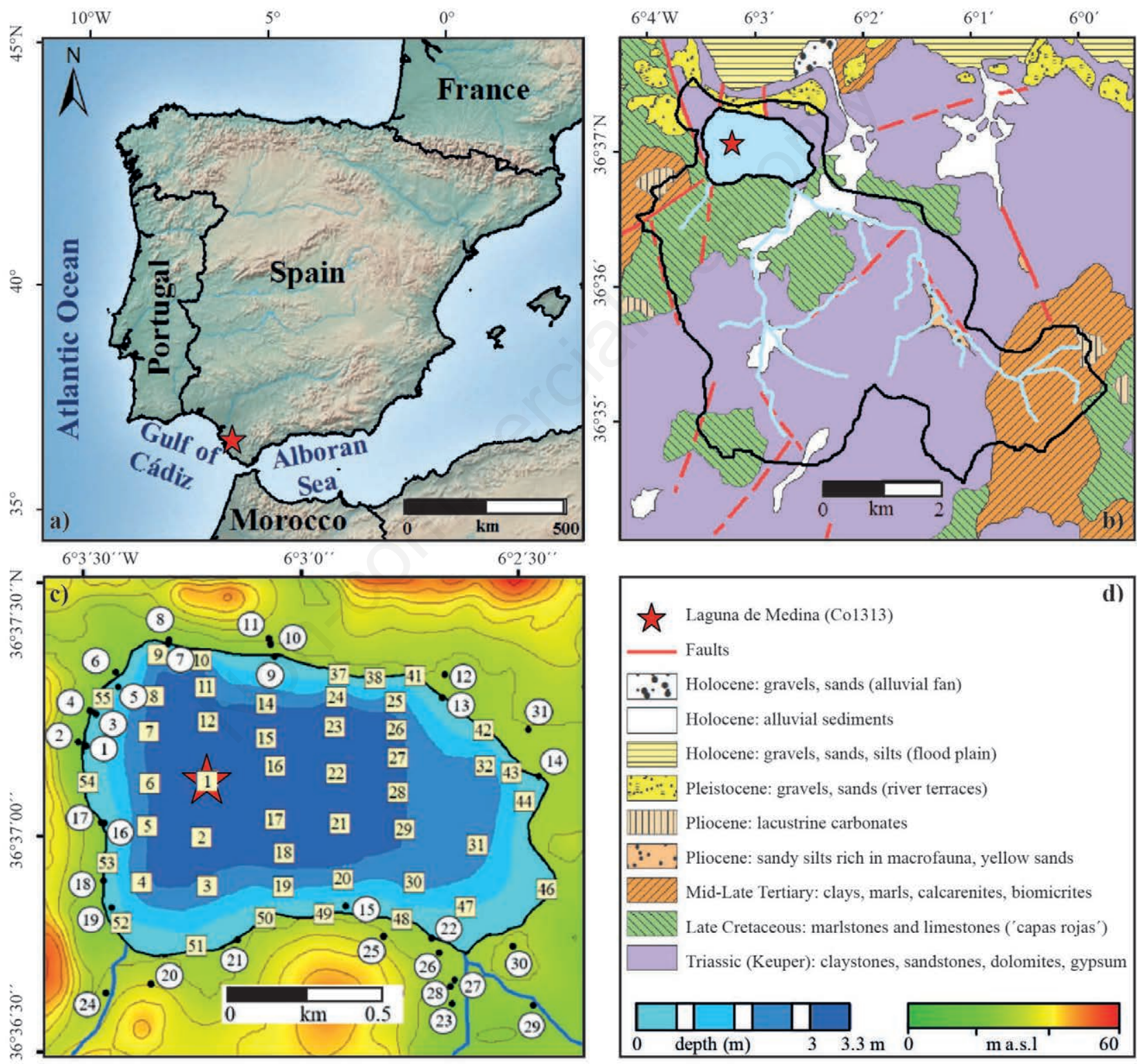

Fig. 1. Maps of the study area. a) Overview of the Iberian Peninsula showing the location of Laguna de Medina (red star). b) Geological map of the surroundings of Laguna de Medina, illustrating major stratigraphic units and fault systems (modified after IGME, 1984). The catchment area is encircled with a black line, the coring location of Co1313 is indicated by a red star. c) Topographic map (green to red $\mathrm{m}$ asl) of the direct surroundings of Laguna de Medina, with the bathymetry (blue in $\mathrm{m}$ ), and locations of lake surface (centre of squares) and catchment soil (black dots) samples. d) Legend for a) b) and c). 
inlet. These samples were collected in September 2014 and March 2015.

The analytical work on the samples was conducted in the laboratories of the University of Cologne. In a first step, the total of 78 samples were freeze-dried, in order to exclude transformation of gypsum $\left(\mathrm{CaSO}_{4} \cdot 2 \mathrm{H}_{2} \mathrm{O}\right)$ to bassanite $\left(\mathrm{CaSO}_{4} \cdot 1 / 2 \mathrm{H}_{2} \mathrm{O}\right)$ or anhydrite $\left(\mathrm{CaSO}_{4}\right)$, which would cause a weight loss of 20.91\% (Stern et al., 1989; Eswaran and Zi-Tong, 1991; Porta, 1998). Subsequently, the bulk sediment samples were split into aliquots for different measurements.

For the grain-size analyses, aliquots of the freeze-dried samples were pretreated with $10 \mathrm{~mL} \mathrm{NaCO}$ at $60^{\circ} \mathrm{C}$ for $18 \mathrm{~h}$ in order to remove gypsum (Stern et al., 1989). Subsequently, carbonate $\left(10 \mathrm{~mL} 10 \% \mathrm{HCl}, 50^{\circ} \mathrm{C}, 3 \mathrm{~h}\right)$, organic matter $\left(5 \mathrm{~mL} 30 \% \mathrm{H}_{2} \mathrm{O}_{2}, 50^{\circ} \mathrm{C}, 18 \mathrm{~h}\right)$, and biogenic silica (5 mL $1 \mathrm{M} \mathrm{NaOH}, 90^{\circ} \mathrm{C}, 2$ x $30 \mathrm{~min}$ ) were removed. Between these steps, the samples were centrifuged and neutralized with deionized water. Before measurements, the samples were mixed with $\mathrm{Na}_{4} \mathrm{P}_{2} \mathrm{O}_{7}(0.05 \%)$ and shaken for at least 12 hours to avoid flocculation of clay minerals. Each sample was measured three times in 116 classes in a range between 0.04 and $2000 \mu \mathrm{m}$ using the Laser Particle Size Analyser LS 13320 (Beckman Coulter Corp., Brea, CA, USA) and the Frauenhofer optical model. The grain-size distributions were calculated using the program GRADISTAT (Blott and Pye, 2001).

The aliquots for mineralogical and geochemical analyses were ground to $<63 \mu \mathrm{m}$ by hand in agate beakers. Bulk mineralogical contents were determined by X-ray diffraction (XRD) on powder pellets using the diffractometer Bruker D8 Discover with $\mathrm{Cu}$ tube $(\lambda=1.5418 \mathrm{~A}, 40 \mathrm{kV}$, $30 \mathrm{~mA}$ ) and the detector LYNXE_XE (opening angle $=2.9464^{\circ}$ ). The spectrum from $5^{\circ}$ to $90^{\circ}$ was measured in 4155 steps of $1 \mathrm{sec}$. exposure time. The evaluation of the spectra to minerals was computed using Match! (Crystal Impact 2014, Bonn, Germany) and SEARCH (Stoe and Cie, Darmstadt, Germany) based on pdf2 (ICDD, Philadelphia, PA, USA). The evaluation of the concentration of the minerals was evaluated using TOPAS Rietveld (Coelho, 2003). Relative element intensities were determined on pressed powder samples using an Xray fluorescence (XRF) scanner (ITRAX; Cox Analytical Systems; Davies et al., 2015). Measurements were performed with $1 \mathrm{~mm}$ resolution and an exposure time of $60 \mathrm{~s}$ using a Cr-tube (settings: $50 \mathrm{kV}, 38 \mathrm{~mA}$ ), which provides a general overview of the elements lighter than $\mathrm{Cr}$ (Löwemark et al., 2011).

For the analyses of total inorganic carbon (TIC) and total organic carbon (TOC), ca. $35 \mathrm{mg}$ samples were mixed with $10 \mathrm{~g}$ of distilled water and measured via the thermal catalytic oxidation principle in the Dimatoc 2000 (Dimatec Corp.). The contents of total nitrogen (TN) and total sulphur (TS) were measured with a vario Micro cube
(Elementar Corp.), in which $5 \mathrm{mg}$ samples were combusted at $1200^{\circ} \mathrm{C}$ in a $\mathrm{He}$ and $\mathrm{O}_{2}$ flow and the element concentrations determined on the $\mathrm{N}_{2}$ and $\mathrm{SO}_{2}$ released by the thermal conductivity detector.

Interpolation and mapping of the data derived from the lake surface sediment and catchment soil samples were carried out by the ArcGIS software by ESRI using the Kriging method (Oliver and Webster, 1990; Cressie, 1991). The principal component analysis (PCA) was conducted with PAST (Hammer et al., 2001).

\section{RESULTS}

The grain-size distributions of the lake surface sediments and the soils in the catchment of Laguna de Medina show a high spatial variability. The lake surface sediments range in mean grain sizes between 4.0 and $362.1 \mu \mathrm{m}$ (Fig. 2a). Coarsest grain sizes, with sand ( $>63 \mu \mathrm{m})$ contents of more than $40 \%$, occur along the northern and western lake shores (Fig. 2b). However, sand is absent at distances $>200 \mathrm{~m}$ from the shore. Here, silt $(2-63 \mu \mathrm{m})$ and clay $(<2 \mu \mathrm{m}$ ) dominate the sediment composition (Fig. 2 $\mathrm{c}, \mathrm{d})$. Highest silt contents $(>60 \%)$ are measured in front of the Arroyo de Fuente Bermeja inlet (Fig. 2b). The clay content is highest in the central part of the lake (Fig. 2d), but with up to $40 \%$ below the silt fraction. The soil samples show coarsest grain sizes, with more than $50 \%$ sand, in the northern catchment, and are much more fine grained than in the other lake areas (Fig. 2).

The mineralogical composition of the lake surface sediment and catchment soil samples is dominated by calcite, quartz, dolomite, and gypsum (Fig. 3). Furthermore, pyrite, muscovite and some clay minerals occur as minor components. Calcite contents are elevated $(>75 \%)$ in soils at the southern shore and in the lake centre (Fig. 3a). The soil samples show highest values in the southern and parts of the western catchments. The quartz contents with $>60 \%$ are highest in the lake sediments close to the northern shore, and reach intermediate values (30-60\%) close to the western and eastern shores (Fig. 3b). This pattern only partly corresponds to the adjacent soil samples, which show similarly high values also in the south-eastern catchment. Dolomite exhibits highest concentrations of $>20 \%$ in the soil samples close to the Arroyo Fuente Bermeja inlet (Fig. 3c). In the lake surface sediments, highest dolomite values of $>4 \%$ occur in front of this inlet, but also close to the north-western lake shore. Gypsum amounts to $<5 \%$ in the lake surface sediments, reaching $>3 \%$ in the western, central, and eastern part of the lake (Fig. 3d). In the catchment soils, the gypsum contents reach values of $>5 \%$ but are patchier and, with the exception of lowest values along the northern shore, do not provide a clear regional pattern.

The bulk elemental composition of the lake surface sediments is dominated by calcium $(\mathrm{Ca})$, which shows at 
least a factor $10^{3}$ higher counts than all other elements. Highest $\mathrm{Ca}$ intensities occur in the southern and southwestern lake areas and in many soil samples from the adjacent catchments (Fig. 4a). Silicon (Si), in contrast, shows highest intensities in the northern lake and catchment (Fig. 4b). Relatively high intensities also occur in front of the inlets reaching the lake in its south-western and south-eastern parts. The distribution of zirconium $(\mathrm{Zr})$ is similar to that of $\mathrm{Si}$, except of a more pronounced minimum at the western shore and more variability of the soil samples in the catchment (Fig. 4c). The strontium (Sr) distribution is rather inversely correlated with $\mathrm{Si}$ and $\mathrm{Zr}$, showing lowest intensities in the north-eastern lake and catchment, and intermediate intensities in the southwestern and south-eastern parts at the inlets (Fig. 4d). Potassium $(\mathrm{K})$ has a distinct maximum in the south-eastern part of the lake, in the vicinity of the Arroyo Fuente Bermeja inlet (Fig. 4e). A very similar pattern is shown by the el- ements aluminium (Al), iron (Fe), titanium (Ti), magnesium $(\mathrm{Mg})$, and rubidium $(\mathrm{Rb})$. The iron/manganese $(\mathrm{Fe} / \mathrm{Mn})$ ratio is higher in the eastern than in the western lake and catchment (Fig. 4f).

TIC is highest $(>5 \%)$ in the southern part of the lake (Fig. 5a). The soil samples show similar values in the adjacent catchment, but also in most parts of the western and eastern catchments. TOC and TN exhibit very similar patterns (Fig. 5 b,c). Distinct maxima occur in the northwestern and eastern lake, with TOC contents of up to $34 \%$ and $23 \%$, respectively, and TN contents of ca. 1.5\%. Relatively high values of $2-6 \%$ TOC and $0.3-0.5 \% \mathrm{TN}$ also occur in the southern and central lake. In the catchment soils TOC and TN concentrations are much lower and show rather irregular patterns with little similarities in adjacent lake and soil samples. The distribution of TS in the lake sediments shows distinct similarities to those of TOC and $\mathrm{TN}$, with the exceptions that extreme values are miss-

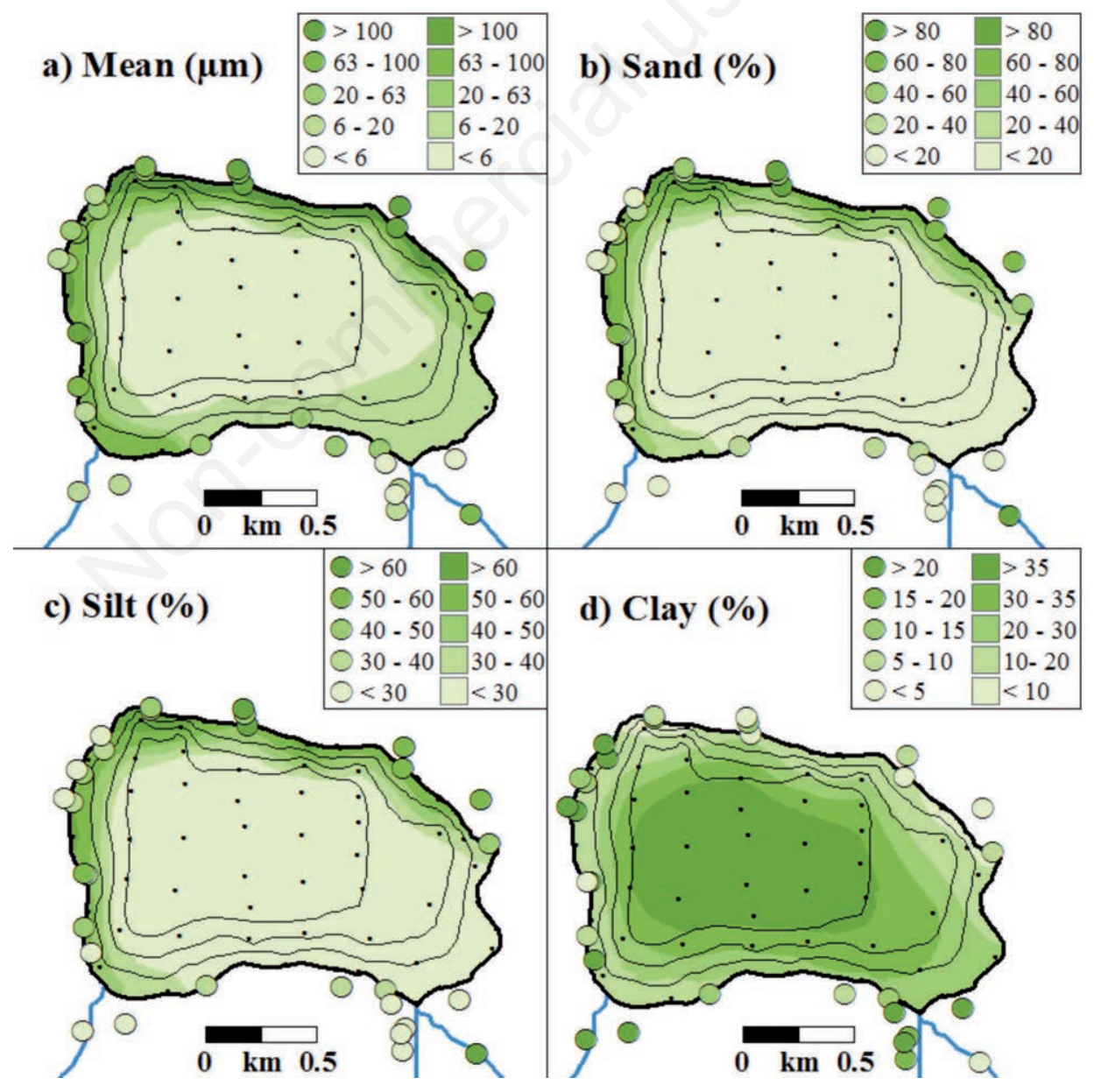

Fig. 2. Spatial distribution of (a) mean grain size and the volume percentages of (b) sand, (c) silt, and (d) clay in the lake surface sediments (black dots) and catchment soil samples (coloured circles). The major inlet streams are indicated by blue lines; contour lines show $1 \mathrm{~m}$ isobaths. 
ing and that the maximum in the western lake sediments is accompanied by relatively high values in the adjacent catchment soils (Fig. 5d). The $\mathrm{C} / \mathrm{N}$ ratio (TOC/TN) shows a rather simple pattern in the lake sediments, with high values of $>10$ along all shores and low values of $<10$ in the lake centre, but more diverse values in the catchment soils (Fig. 5e). The $\mathrm{C} / \mathrm{S}$ (TOC/TS) ratio (2.7-25.7) has some similarities in the lake sediments with the $\mathrm{C} / \mathrm{N}$ ratio, however, the maxima are restricted to small areas at the north-western, south-western, and eastern shores, and they correspond with maxima in several soil samples from their adjacent catchments (Fig. 5f).

The first and second principal components (PC) of the principal component analysis (PCA) of the lake surface sediments of Laguna de Medina explain $55.44 \%$ and $16.79 \%$ of the data, respectively (Fig. 6). The outcome plots within the $95 \%$ confidence ellipse. Negative loadings of $\mathrm{PC} 1$ are found by sand, the mean grain size, $\mathrm{Si}$,
$\mathrm{Zr}$, quartz and $\mathrm{C} / \mathrm{N}$ and $\mathrm{C} / \mathrm{S}$ ratios. Positive loadings are reflected by the water depth, the fine-grained fractions (clay and silt), gypsum, calcite and TIC and Mn. Positive loadings of PC2 are reflected by TOC, TN and TS. Negative loadings include the elements $\mathrm{Ti}, \mathrm{K}, \mathrm{Al}, \mathrm{Rb}, \mathrm{Fe}$ and $\mathrm{Mg}$ and dolomite.

\section{DISCUSSION}

Based on the granulometric, mineralogical, and geochemical parameters (Figs. 2-5), supported by the PCA (Fig. 6), the lake surface sediment samples of Laguna de Medina can be divided into six provinces of individual compositions and depositional processes (Fig. 7).

At the northern shore (Province I), the lake surface sediments differ from those in all other parts of the lake by particularly coarse grain sizes, with high sand contents

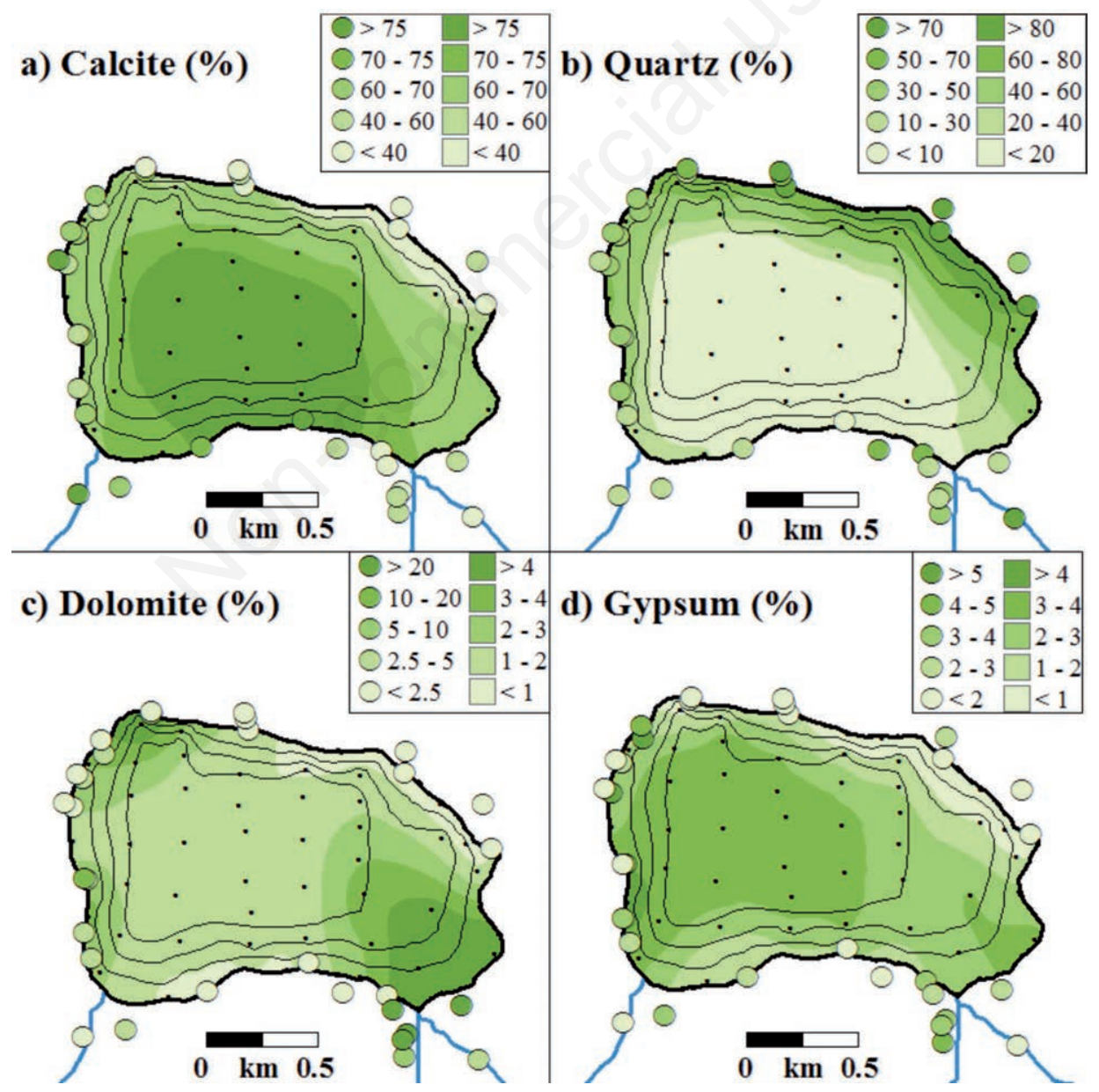

Fig. 3. Spatial distribution of the volume percentages of (a) calcite, (b) quartz, (c) dolomite, and (d) gypsum in the lake surface sediments (black dots) and catchment soil samples (coloured circles). The major inlet streams are indicated by blue lines; contour lines show $1 \mathrm{~m}$ isobaths. 
and a mean grain size of 100-362 $\mu \mathrm{m}$ (Fig. 2 a,b). Furthermore, quartz, Si, and $\mathrm{Zr}$ are clearly enriched (Figs. 3b and $4 \mathrm{~b}, \mathrm{c})$. All these proxies have high negative loadings on the PC1 in common (Fig. 6) and a very similar com- position is found in the soil samples to the north of the lake. This suggests that sediment supply into the lake from the palaeoriver terraces of the Guadalete to the north, which consist of conglomerates, sands and gravels

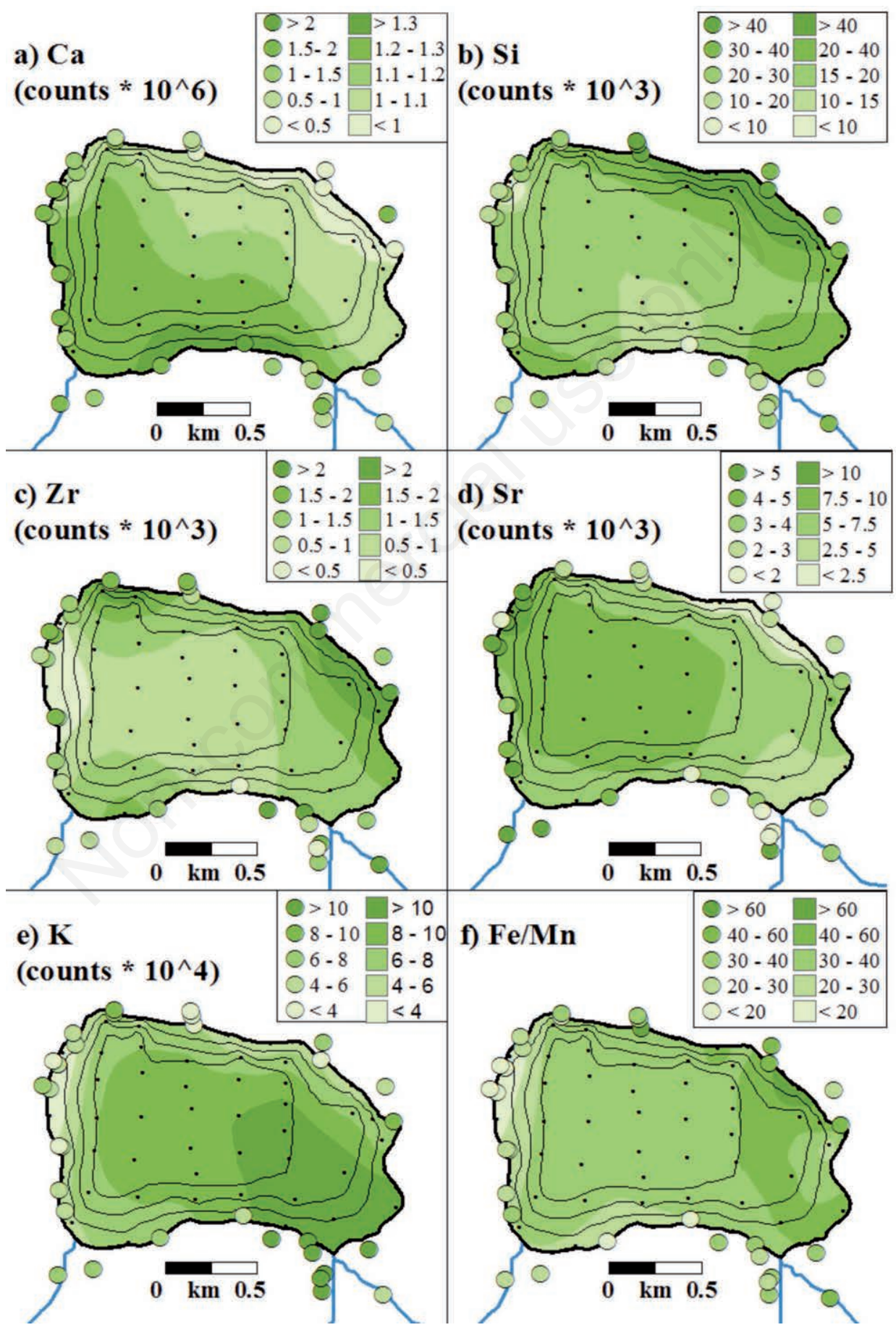

Fig. 4. Spatial distribution of counts of (a) $\mathrm{Ca}$, (b) $\mathrm{Si}$, (c) $\mathrm{Zr}$, (d) $\mathrm{Sr}$, (e) $\mathrm{K}$, and (f) the ratio of Fe/Mn in the lake surface sediments (black dots) and catchment soil samples (coloured circles). The major inlet streams are indicated by blue lines; contour lines show $1 \mathrm{~m}$ isobaths. 
(IGME, 1984), dominates the sedimentation close to the northern lake shore.

Province II occurs in the southeastern part of the lake, in front of the Fuente Bermeja inlet. The sediments are characterized by high contents of silt (Fig. 2b), as well as high intensities of lithogenic elements such as K (Fig. 4e), $\mathrm{Al}, \mathrm{Fe}, \mathrm{Ti}, \mathrm{Mg}$ and $\mathrm{Rb}$ (not shown; Boës et al., 2011), as well as dolomite (Fig. 3c). A similar composition is found

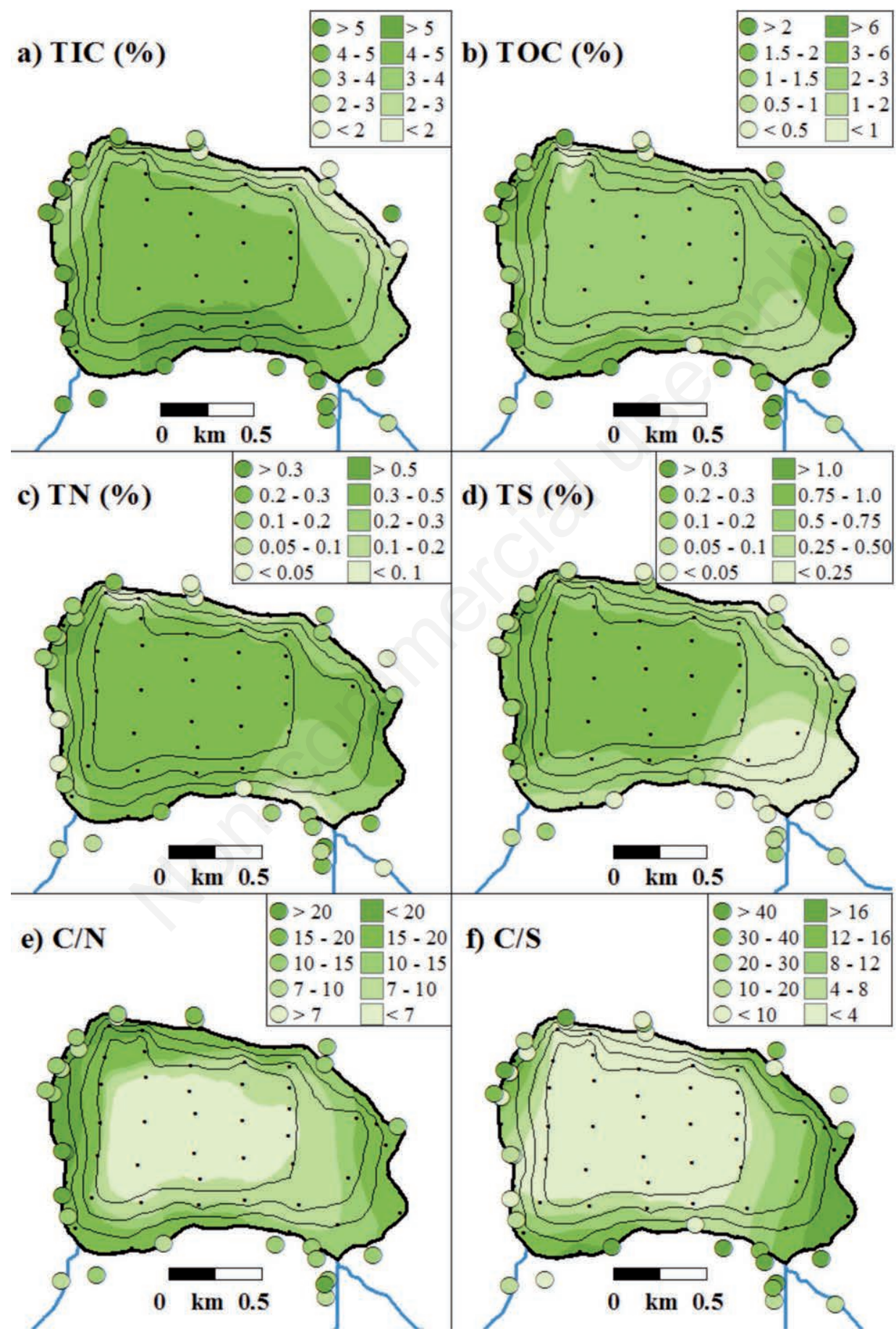

Fig. 5. Spatial distribution of the volume percentages of (a) TIC, (b) TOC, (c) TN, (d) TS and the ratios of (e) C/N and (f) C/S in the lake surface sediments (black dots) and catchment soil samples (coloured circles). The major inlet streams are indicated by blue lines; contour lines show $1 \mathrm{~m}$ isobaths. 
in the fluvial sediments of the Fuente Bermeja and most of the adjacent soil samples, thus indicating that lake sediment composition is strongly influenced of riverine input by this major inlet. The chemical and mineralogical composition of the lake sediments suggests that the Fuente Bermeja mainly supplies weathering products of the Triassic Keuper facies, which is widely exposed in the catchment and consists of claystones, sandstones, and partly dolomites (IGME, 1984; Fig. 1c). The dominance of this sediment source is also reflected by a distinct clustering of dolomite and the lithogenic elements in the PCA, showing positive loadings of $\mathrm{PC} 1$ and high negative loadings of PC2. Interestingly, dolomite clusters closer to the lithogenic elements than to the $\mathrm{Ca}$. $\mathrm{Ca}$ is dominating in the entire lake, so an extra $\mathrm{Ca}$ input from dolomite is not significant. The effect of the $\mathrm{Mg}$, on the other hand, is much more pronounced. That is the reason the dolomites cluster close to the lithogenic elements. The high silt contents of the surface sediments, and its wide distribution throughout the lake (Fig. 2b), reflect the main grain size provided by the inlet, but also that this fluvial input constitutes a significant contribution to sedimentation also in other lake parts.

The lake sediments close to the southern shore (Province III) are characterized by high calcite and TIC concentrations, and high $\mathrm{Ca}$ intensities (Figs. 3a, 4a, 5b). In the PCA, these proxies show positive loadings in PC1 but negative loadings in PC2. The latter suggests a significantly different sediment source to that of the northern shore (Province I), which is characterized by high concen- trations of sediment proxies with positive PC2 loadings that reflect clastic sediment supply. The carbonate-related proxies enriched in Province III, in contrast, rather suggest supply of weathering products from the adjacent Cretaceous 'capas rojas', a series of Subbetic deep-water marlstones and limestones occurring to the south (IGME, 1984; Vera and Molina, 1999). This sediment source is also reflected in the composition of the soil surface samples to the south of the lake.

Province IV is located in the western part of the lake (Fig. 7). It is characterized by high gypsum and TS concentrations, high $\mathrm{Sr}$ intensities, and $\mathrm{C} / \mathrm{N}$ ratios $>12$ (Figs. $3 \mathrm{~d}, 4 \mathrm{~d}, 5 \mathrm{~d}, \mathrm{e})$. The high $\mathrm{C} / \mathrm{N}$ ratios indicate a high terrestrial influence on organic matter deposition (Meyers and Ishiwatari, 1993). The relatively high $\mathrm{Sr}$ concentration could partly be traced back to the Cretaceous carbonates, such as those in the 'capas rojas' to the south, but also supports direct gypsum supply, which is suggested by elevated gypsum contents. In both cases, $\mathrm{Sr}$ is partly related to Ca (Kulp et al., 1952). A Ca, TS, and Sr supply in parts independent on the gypsum supply is also indicated in the PCA, where gypsum loadings around zero on PC2 differ from distinctly negative loadings of $\mathrm{Ca}, \mathrm{TS}$, and $\mathrm{Sr}$ (Fig. 6 ). The most likely source for terrestrial gypsum supply in Province IV is the western lake catchment. There, however, a patchy pattern in the respective soil samples (Fig. $3 d)$ suggests that gypsum is exposed to the surface only locally. Therefore, the high gypsum, Sr, and TS concentrations in Province IV, partly extending further towards the lake centre (Province VI), most likely originate not

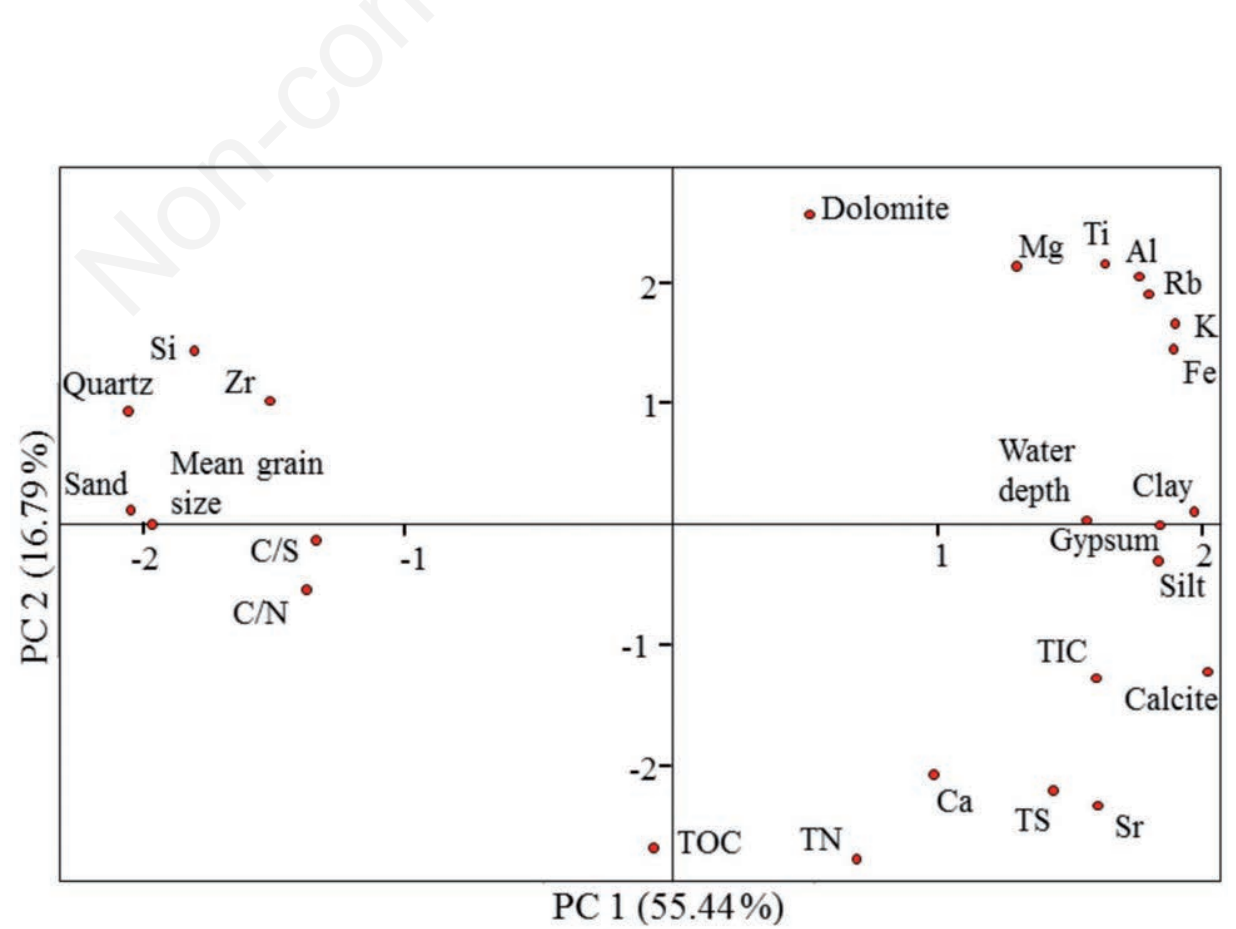

Fig. 6. Results of the principal component analysis (PCA) of the granulometric, mineralogical, elemental, and geochemical parameters. 
only from surficial gypsum and carbonate supply but also from infiltrating groundwater, which is enriched with dissolved $\mathrm{Ca}$ and $\mathrm{SO}_{4}$ ions (Burn and Palmer, 2014). This suggestion is supported by low $\mathrm{C} / \mathrm{S}$ values in the centre of the lake (Fig. 5f), which suggest an enrichment of TS by gypsum accumulation.

Province V is divided into two areas in the north-western and central eastern parts of the lake. These areas are highly enriched in TOC and TN concentrations (Fig. 5 a,c), indicating an increased amount of organic matter. TS is moderately enriched in these areas (Fig. 5d), suggesting that the sulphur is also partly adsorbed onto organic matter, and not only on the gypsum. This is also visible in the PCA, where TS plots between the organic compounds TOC and $\mathrm{TN}$ and the gypsum (Fig. 6). Adjacent to the areas in the north-western and central eastern parts of the lake, much land is dedicated to agricultural use, like dry cultivation of cereals and sunflower (Reed et al., 2001), using the lake water for irrigation (Fernández-Palacios, 1990). Small gul- lies, which drain these agricultural areas enter the lake in both of the Provinces V. Hence, the higher TOC and TN concentrations in this province are probably an anthropogenic effect, with more terrestrial organic matter being mobilized and transported into the lake.

Province VI is situated in the 'deep' centre of the lake, where the influences of wave action and punctuated catchment supply are smallest. Here, low energy favours fine particles as clay and silt to settle (Fig. 2 b,c). Sedimentation of gypsum and calcite is significant (Fig. 3 a,c), with the former also being reflected by low $\mathrm{C} / \mathrm{S}$ ratios (Fig. $5 \mathrm{f}$ ). $\mathrm{C} / \mathrm{N}$ ratios of $<10$ (Fig. 5e) suggest that the organic matter in the surface sediments originates mainly from autochthonous in-lake productivity (algae), with only restricted contribution from terrestrial sources (Meyers and Ishiwatari, 1993). These interpretations are supported by PC1 of the PCA analysis, showing high positive loadings of clay, silt, gypsum, and calcite, and high negative loadings of $\mathrm{C} / \mathrm{S}$ and $\mathrm{C} / \mathrm{N}$ (Fig. 6).

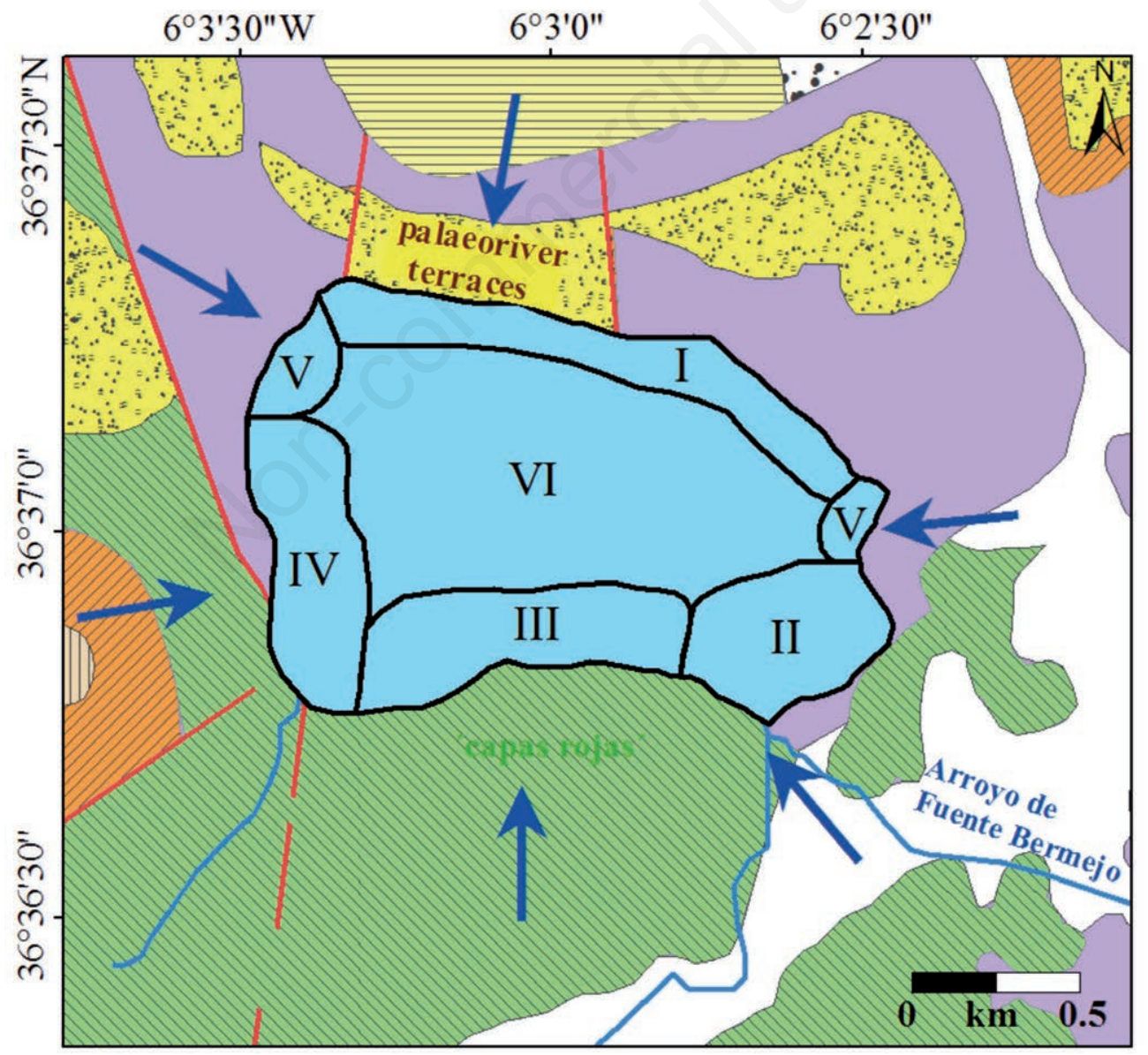

Fig. 7. Geology in the near surroundings of the Laguna de Medina (cf. Fig. 1) and spatial distribution of the six provinces of lake surface sediments with individual compositions and driving forces: I, input from palaeo river terraces; II, fluvial sediment supply; III, 'capas rojas' influence; IV, gypsum precipitation; V, anthropogenic terrestrial organic matter supply; VI, distal background sedimentation. 


\section{CONCLUSIONS}

Based on the granulometric, mineralogical, elemental, and geochemical composition of the surface sediments in the Laguna de Medina, and the comparison with the composition of catchment soil samples, the following conclusions can be drawn concerning the modern sedimentation in this lake.

Today, regional differences in the sedimentation in the Laguna de Medina, as documented in the sedimentary provinces I to VI (Fig. 7), are predominantly controlled by the surrounding geology. This is mainly reflected in the mineralogical and elemental composition of the surface sediments, showing enrichments of quartz, dolomite, calcite, and gypsum, along with the associated elements, close to the northern, south-eastern, southern, and western shores, respectively. In addition, enhanced organic matter deposition due to anthropogenic activity in the catchment is indicated close to the eastern and north-western shores. In the central part of the lake, with a distance greater than $200 \mathrm{~m}$ from the shores, sediments are significantly more mixed, even if the sediment supply from the major inlet Arroyo de Fuente Bermejo could be still detected.

No indication was found that lake currents have a strong impact on the modern sediment distribution in the Laguna de Medina. This differentiates this small endorheic lake from larger throughflow lakes, such as Lake Ohrid in the eastern Mediterranean area (Vogel et al., 2010) and Lake El'gygytgyn in the north-eastern Russian Arctic (Wennrich et al., 2013). Furthermore, the Laguna de Medina today obviously is too shallow to have significant areal differences in bottom water redox conditions. This is for instance reflected in a $\mathrm{Fe} / \mathrm{Mn}$ ratio independent on water depth (Fig. 4f), a proxy that in deeper lakes, such as Lake El'gygytgyn, can be used to reconstruct times of anoxic bottom water conditions (Melles et al., 2012). Another difficulty is the double roll of Calcium, because it is partly bound on the calcite and also on the gypsum, so the Ca intensities cannot be used as a proxy for calcite in this lake.

Taking these findings concerning the modern sedimentation in the Laguna de Medina, sediment cores from the central part of the lake should reflect quite well how the identified driving forces have changed in their relative importance throughout the last millennia. Hence, the $25.7 \mathrm{~m}$ long core Co1313 recovered from the central part of the Laguna de Medina from its location and length has a high potential to provide new important insights into the regional climatic and environmental conditions in southern Spain during Late Quaternary times.

\section{ACKNOWLEDGMENTS}

This paper was developed within the framework of the CRC 806 'Our Way to Europe' supported by the German
Research Foundation (DFG). We thank Nicole Mantke and Dorothea Klinghardt (University of Cologne) for their technical assistance in the laboratory. Furthermore, we like to thank Anne-Sophie Mreyen for the help with the DEM and the GIS maps and Christian Steffens for the help during the sampling and analysing. Special thanks go to the guards from the nature reserve Laguna de Medina for their support and hospitality and to the Junta de Andalucía for the permission to core in the lake.

\section{REFERENCES}

Blott SJ, Pye K, 2001. Technical Communication Gradistat: a grain size distribution and statistics package for the analysis of unconsolidated sediments. Earth Surf. Process. Landf. 26:1237-1248

Boes X, Rydberg J, Martinez-Cortizas A, Bindler R, Renberg I, 2011. Evaluation of conservative lithogenic elements (Ti, $\mathrm{Zr}, \mathrm{Al}$, and $\mathrm{Rb}$ ) to study anthropogenic element enrichments in lake sediments. J. Paleolimnol. 46:75-87.

Burn MJ, Palmer SE, 2014. Solar forcing of Caribbean drought events during the last millennium. J. Quaternary Sci. 29: 827-836.

Coelho AA, 2003. Indexing of powder diffraction patterns by iterative use of singular value decomposition. J. Appl. Crystallogr. 36:86-95.

Cressie NAC, 1991. Statistics for spatial data. John Wiley \& Sons, Hoboken: 928 pp.

Davies SJ, Lamb HF, Roberts SJ, 2015. Micro-XRF core scanning in palaeolimnology: recent developments, p. 189-226. In: I.W. Croudace and R.G. Rothwell (eds.), Micro-XRF studies of sediment cores. Springer.

de Castro M, Martín-Vide M, Alonso S, 2004. The climate of Spain: past, present and scenarios for the $21^{\text {st }}$ century, p. 162. In: M. de Castro, M. Martín-Vide and S. Alonso (eds.), Impacts of climatic change in Spain. Available from: http://ecce.uclm.es/ documentos/version0_ingles/01_climate_ing.pdf

de Vicente I, López R, Pozo I, Green AJ, 2012. Nutrient and sediment dynamics in a Mediterranean shallow lake in southwest Spain. Limnetica 31:231-250.

Dorman CE, Beardsley RC, Limeburner R, 1995. Winds in the Strait of Gibraltar. Q. J. R. Meteorol. Soc. 121:1903-1921.

Durán Valsero JJ, García de Domingo A, Robledo Ardila P, 2009. [Propuesta de clasificación genético-geológica de humedales. Aplicación a los humedales españoles incluidos en el Convenio de Ramsar].[Article in Spanish]. Bolétin Geológico y Minero 120:335-346.

Eswaran H, Zi-Tong G, 1991. Properties, genesis, classification, and distribution of soils with gypsum, p. 89-119. In: W.D. Nettleton (ed.), Occurrence, characteristics, and genesis of carbonate, gypsum, and silica accumulations in soils. SSSA Special Publication 26. Soil Science Society of America, Fitchburg.

Eugster HP, Hardie LA, 1978. Saline lakes, p. 37-293. In: A Lerman (ed.), Lakes - chemistry, geology, physics. Springer, New York.

Fernández-Palacios JM, 1990. [Lagunas de Cádiz (Medina y 
Salada)], p. 9-24. In: A. Panduro and M. Bernués Sanz M (eds.), [Trova Humedales Espanoles en la lista der convenio de ramsar].[Book in Spanish]. Ministerio de Agricultura. Pesca y Alimentación, Instituo Nacional para la Conservación de la Naturaleza, Madrid.

Fletcher WJ, Boski T, Moura D, 2007. Palynological evidence for environmental and climatic change in the lower Guadiana valley, Portugal, during the last 13000 years. Holocene 17:481-494.

Furest A, Toja J, 1984. [Reconocimiento limnológico de lagunas andaluzas]. In: Agencia de Medio Ambiente (ed.), [Las zonas húmedas en Andalucía].[Book in Spanish]. Monografías de la Dirección General de Medio Ambiente, Madrid.

Hammer Ø, Harper DAT, Ryan PD, 2001. Paleontological statistics software package for education and data analysis. Palaeontol. Electron. 4:9-18.

IGME, 1984. [Mapa Geologico de España; E. 1:50000].[In Spanish]. Paterna de Rivera, Madrid.

Kulp JL, Turekian KK, Boyd DW, 1952. Strontiom content of limestones and fossils. Bull. Geol. Soc. Amer. 63:710-716.

Löwemark L, Chen HF, Yang TN, Kylander M, Yu EF, Hsu YW, Lee TQ, Song SR, Jarvis S, 2011. Normalizing XRF-scanner data: A cautionary note on the interpretation of high-resolution records from organic-rich lakes. J. Asian Earth Sci. 40:1250-1256.

Marazanof F, 1967. Ostracodes, cladoceres, hétéropteres et hydracariens nouveaux pour les Marismas du Guadalquivir (Andalousie). Ann. Limnol. 3:47-64.

Martinez-Ruiz F, Kastner M, Gallego-Torres D, Rodrigo-Gámiz M, Nieto-Moreno V, Ortega-Huertas M, 2015. Paleoclimate and paleoceanography over the past $20,000 \mathrm{yr}$ in the Mediterranean Sea Basins as indicated by sediment elemental proxies. Quat. Sci. Rev. 107:25-46.

Martin-Puertas C, Valero-Garces BL, Pilar Mata M, GonzalezSamperiz P, Bao R, Moreno A, Stefanova V, 2008. Arid and humid phases in southern Spain during the last 4000 years: the Zoñar Lake record, Cordoba. Holocene 18:907-921.

Martrat B, Jimenez-Amat P, Zahn R, Grimalt JO, 2014. Similarities and dissimilarities between the last two deglaciations and interglaciations in the North Atlantic region. Quat. Sci. Rev. 99:122-134.

Medialdea T, Somoza L, Pinheiro LM, Fernández-Puga MC, Vázquez JT, León R, Ivsnov MK, Magelhaes V, Díaz-delRío V, Vegas R, 2009. Tectonics and mud volcano development in the Gulf of Cádiz. Mar. Geol. 261:48-63.

Melles M, Brigham-Grette J, Minyuk PS, Nowaczyk NR, Wennrich V, Deconto RM, Anderson PM, Andreev AA, Coletti A, Cook TL, Haltia-Hovi E, Kukkinen M, Lozhkin AV, Rosén P, Tarasov P, Vogel H, Wagner B, 2012. 2.8 million years of arctic climate change from Lake El'gygytgyn, NE Russia. Science 337:315-320.

Meyers PA, Ishiwatari R, 1993. Lacustrine organic geochemistry - an overview of indicators of organic matter sources and diagenesis in lake sediments. Org. Geochem. 20:867-900.

Meteorological Office, 1962. Weather in the Mediterranean. Gen. Meteorol. I. Her Majesty's Stationery Office, London.

Met Office, 2011. Climate: observations, projections and impacts. Available from: http://www.metoffice.gov.uk/climateguide/science/uk/obs-projections-impacts

Oliver MA, Webster R, 1990. Kriging: a method of interpolation for geographical information systems. Int. J. Geogr. Inf. Syst. 4: 313-332.

Paez M, 1991. [Los humedales endorréicos gaditanos encuadre geográfico comarcal, p. 25-46]. In: Agencia de Medio Ambiente (ed.), [Plan rector de uso y gestíon de las reservas naturales de las lagunas de Cádiz].[Report in Spanish]. Agencia de Medio Ambiente, Cádiz.

Peel MC, Finlayson BL, McMahon TA, 2007. Updated world map of the Köppen-Geiger climate classification. Hydrol. Earth Syst. Sci. 11:1633-1644.

Pons A, Reille M, 1988. The holocene- and upper pleistocene pollen record from Padul (Granada, Spain): aA new study. Palaeogeogr. Palaeoclimatol. Palaeoecol. 66:243-263.

Porta J, 1998. Methodologies for the analysis and characterization of gypsum in soils: A review. Geoderma 87:31-46.

Reed JM, Stevenson AC, Juggins S, 2001. A multi-proxy record of Holocene climatic change in southwestern Spain: the Laguna de Medina, Cádiz. Holocene 11: 707-719.

Rodrigo FS, Pozo-Vázquez D, Esteban-Parra MJ, Castro-Díez Y, 2001. A reconstruction of the winter North Atlantic Oscillation index back to A.D. 1501 using documentary data in southern Spain. J. Geoph. Res. 106:14805-14818.

Rodriguez Vidal J, Gracia FJ, Giles J, 1993. [Deformacíones cuaternarias en la terraza fluvial de la Laguna de Medina (Río Guadalete, Jerez de la Frontera)].[Article in Spanish]. Rev. Soc. Geol. España 6:47-55.

Stern R, Alperovitch N, Levy G, 1989. Rapid removal of gypsum by resin prior to particle-size-distribution analysis in soils. Soil Sci. 148: 448-451.

Stocker TF, Qin D, Plattner GK, Tignor M, Allen SK, Boschung J, Nauels A, Xia Y, Bex B, Midgley BM, 2013. IPCC, 2013: Climate change 2013 - The physical science basis. Annex I: atlas of global and regional climate projections. Contribution of working group I to the Fifth Assessment Report of the Intergovernmental Panel on climate change. Cambridge University Press, Cambridge.

Tello Ripa B, López Bermúdez F, 1988. [Los lagos. Guía física de España.4].[Book in Spanish]. Alianza Editorial, Madrid: 468 pp.

Toucanne S, Mulder T, Schönfeld J, Hanquiez V, Gonthier E, Duprat J, Cremer M, Zaragosi S, 2007. Contourites of the Gulf of Cadiz: A high-resolution record of the paleocirculation of the Mediterranean outflow water during the last 50,000 years. Palaeogeogr. Palaeoclimatol. Palaeoecol. 246: 354-366.

Valero-Garcés B, Morellón M, Moreno A, Corella JP, MartínPuertas C, Barreiro F, Pérez A, Giralt S, Mata-Campo MP, 2014. Lacustrine carbonates of Iberian Karst Lakes: Sources, processes and depositional environments. Sedim. Geol. 299:1-29.

Vegas J, Ruiz-Zapata B, Ortiz JE, Galán L, Torres T, GarcíaCortés Á, Gil-García MJ, Pérez-González A, Gallardo-Millán JL, 2010. Identification of arid phases during the last 50 cal. ka BP from the Fuentillejo maar-lacustrine record (Campo de Calatrava Volcanic Field, Spain). J. Quat. Sci. 25: 1051-1062.

Vera JA, Molina JM, 1999. [La formacion Capas Rojas: Caracterizacíon y genesis].[Article in Spanish]. Estudios Geologi$\cos 55: 45-66$.

Voelker AHL, de Abreu L, 2011. A review of abrupt climate change events in the Northeastern Atlantic Ocean (Iberian 
Margin): Latitudinal, longitudinal, and vertical gradients. Geophys. Monogr. Ser. 193:15-37.

Vogel H, Wessels M, Albrecht C, Stich HB, Wagner B, 2010. Spatial variability of recent sedimentation in Lake Ohrid (Albania/Macedonia). Biogeosciences 7: 3333-3342.

von Storch H, Zorita E, Cubasch U, 1993. Downscaling of global climate change estimates to regional scales: an application to Iberian rainfall in wintertime. J. Clim. 6:1161-1171.

Wennrich V, Francke A, Dehnert A, Juschus O, Leipe T, Vogt C, Brigham-Grette J, Minyuk PS, Melles M, El'gygytgyn Sci- ence Party, 2013. Modern sedimentation patterns in Lake El'gygytgyn, NE Russia, derived from surface sediment and inlet streams samples. Clim. Past 9:135-148.

Wolf D, Faust D, 2015. Western Mediterranean environmental changes: evidences from fluvial archives. Quat. Sci. Rev. 122:30-50.

Wolf D, Seim A, Faust D, 2014. Fluvial system response to external forcing and human impact - Late Pleistocene and Holocene fluvial dynamics of the lower Guadalete River in western Andalucía (Spain). Boreas 43:422-449. 